\title{
The anti-inflammatory mechanisms of Hsp70
}

\section{Thiago J. Borges ${ }^{1 \dagger}{ }^{\dagger}$ Lotte Wieten ${ }^{2 \dagger}$, Martijn J. C. van Herwijnen ${ }^{2}$, Femke Broere ${ }^{2}$, Ruurd van der Zee ${ }^{2}$, Cristina Bonorino ${ }^{1 *}$ and Willem van Eden ${ }^{2}$}

${ }^{1}$ Faculdade de Biociências e Instituto de Pesquisas Biomédicas, Pontifícia Universidade Católica do Rio Grande do Sul, Porto Alegre, Rio Grande do Sul, Brazil

${ }^{2}$ Department of Infectious Diseases and Immunology, Faculty of Veterinary Medicine, Utrecht University, Utrecht, Netherlands

\section{Edited by:}

Alexander Rudensky, Memorial

Sloan-Kettering Cancer Center, USA

Reviewed by:

Francesco Annunziato, University of Florence, Italy

Miriam Wittmann, University of

Leeds, UK

\section{*Correspondence.}

Cristina Bonorino, Departamento de Biologia Celular e Molecular e Instituto de Pesquisas Biomédicas, Pontifícia Universidade Católica do Rio Grande do Sul, Av. Ipiranga, $66902^{\circ}$ andar, 90680-001 Porto Alegre, Rio Grande do Sul, Brazil.

e-mail: cbonorino@pucrs.br;

Willem van Eden, Department of Infectious Diseases and Immunology,

Faculty of Veterinary Medicine,

Utrecht University, Yalelaan 1, 3584

CL Utrecht, Netherlands.

e-mail:w.vaneden@uu.nl

${ }^{\dagger}$ Thiago J. Borges and Lotte Wieten have contributed equally to this work.
Immune responses to heat shock proteins (Hsp) develop in virtually all inflammatory diseases; however, the significance of such responses is only now becoming clear. In experimental disease models, Hsp administration can prevent or arrest inflammatory damage, and in initial clinical trials in patients with chronic inflammatory diseases, Hsp peptides have been shown to promote the production of anti-inflammatory cytokines, indicating immunoregulatory potential of Hsp. Therefore, the presence of immune responses to Hsp in inflammatory diseases can be seen as an attempt of the immune system to correct the inflammatory condition. Hsp70 can modulate inflammatory responses in models of arthritis, colitis and graft rejection, and the mechanisms underlying this effect are now being elucidated. Incubation with microbial Hsp70 was seen to induce tolerogenic dendritic cells (DCs) and to promote a suppressive phenotype in myeloid-derived suppressor cells and monocytes. These DC could induce regulatory T cells (Tregs), independently of the antigens they presented. Some Hsp70 family members are associated with autophagy, leading to a preferential uploading of Hsp70 peptides in MHC class II molecules of stressed cells. Henceforth, conserved Hsp70 peptides may be presented in these situations and constitute targets of Tregs, contributing to downregulation of inflammation. Finally, an interfering effect in multiple intracellular inflammatory signaling pathways is also known for Hsp70. Altogether it seems attractive to use Hsp70, or its derivative peptides, for modulation of inflammation. This is a physiological immunotherapy approach, without the immediate necessity of defining disease-specific auto-antigens. In this article, we present the evidence on anti-inflammatory effects of Hsp70 and discuss the need for experiments that will be crucial for the further exploration of the immunosuppressive potential of this protein.

Keywords: Hsp70, stress proteins, immunomodulation, adaptive immunity, innate immunity

\section{Hsps ARE IMMUNODOMINANT PROTEINS}

Heat shock proteins (Hsp) are highly conserved proteins, from microbes through mammals. They are preferentially induced in response to cell stresses including heat shock, oxidative stress, ultraviolet radiation, ischemia-reperfusion injury, viral infections, nutrient deprivation, and chemicals (Lindquist, 1986), protecting cells from injury and promoting refolding of denatured proteins. Hsp are grouped in families according to their molecular weight, and constitutive members of each family can be found in different cell compartments under non-stress conditions, performing chaperone functions (Lindquist and Craig, 1988).

Hsp70 is the most highly conserved protein known to date (Lindquist and Craig, 1988; Ellis, 1990; Feder and Hofmann, 1999). It was therefore surprising when Hsp, including Hsp70, were found to be immunodominant antigens. Early studies demonstrated that 10-20\% of the T cells recognized Hsp60 of Mycobacterium tuberculosis after experimental mycobacterial immunization (Kaufmann et al., 1987). Hsp70 of M. leprae was shown to be a prominent antigen in humans infected with $M$. leprae (Kaufmann et al., 1987; Janson et al., 1991). Such mycobacterial-Hsp-specific T cell responses have also been observed in healthy individuals, not previously exposed to mycobacterial infections (Munk et al., 1989) and in cord blood (Fischer et al., 1992; Aalberse et al., 2011). Immunization with Hsp70 of M. tuberculosis (TB-Hsp70) led to a strong IgG response in 7 days without evidence of IgM production (Bonorino et al., 1998), suggesting that antigen-specific T cells able to provide help were already available in naïve mice. Interestingly, a detailed analysis of the peptides recognized by $\mathrm{T}$ cells, both in healthy and infected individuals, revealed that some of them were highly conserved (Quayle et al., 1992; Anderton et al., 1995).

\section{Hsp70 AS AN IMMUNOMODULATORY AGENT}

It was then hypothesized that, because of their homology with self, bacterial-Hsp would provoke autoimmunity through molecular mimicry with self-proteins. This idea was refuted by the finding that pre-immunization with bacterial-Hsp protected Lewis rats from adjuvant-induced arthritis (van Eden et al., 1988). Subsequently, immunoregulatory features of Hsp were demonstrated in various inflammatory diseases. The literature on immunomodulatory properties of $\mathrm{Hsp}$ is vast. In this review, we will focus on Hsp70. Although it may be tempting to generalize observations on different Hsp, it is important to consider that the different families of Hsp show no homology of sequence or structure, and are encoded by different genes, transcribed under the control 
of different transcription factors, that are not always activated in coordinate manner. Rather, Hsp are grouped under the same banner because they are commonly induced in similar situations of stress, cooperating to promote cell recovery and protection from injury.

Hsp70 was demonstrated to have a disease suppressive role in experimental models of autoimmunity. One study demonstrated that $\mathrm{T}$ cells reactive to peptide 234-252 of TB-Hsp70 suppressed inflammatory responses against Listeria monocytogenes via production of IL-10 (Kimura etal., 1998). The same group later showed that pretreatment with peptide 234-252 of TB-Hsp70 suppressed the development of adjuvant-induced arthritis in Lewis rats, generating $\mathrm{T}$ cells that were specific for this peptide, and produced high levels of IL-10, but not IFN-g (Tanaka et al., 1999). Also the treatment with anti-IL-10 antibody abrogated protection. This peptide showed $58 \%$ amino acid identity between rat and mycobacterial Hsp70. Another study revealed that a different peptide of Hsp70, conserved between rat and mycobacteria, protected Lewis rats from development of arthritis when given intra-nasally (Wendling et al., 2000), preventing disease development by the induction of IL-10 producing T cells. Endogenous Hsp70 presence in the mouse, guaranteed by the presence of heat shock factor 1 (HSF1), its transcription factor, was found to protect from induced colitis (Tanaka et al., 2007). More recently, treatment with whole endotoxin-free TB-Hsp70 inhibited acute rejection of skin and tumor allografts (Borges et al., 2010). Consequently, disease suppressive effects have been observed in the case of both microbial and self (mammalian) Hsp70, some studies using whole protein, some studies using just the peptide, and IL-10 was always important.

How could the conservation of Hsp be reconciled with this apparent predisposition for recognition by the immune system? One idea was that the protective effects of microbial Hsp were related, at least in part, to their capacity to induce $\mathrm{T}$ cell responses which were cross-reactive with self-Hsp. Cohen proposed that, to avoid excessive immune responses to both selfand foreign-antigens, the immune system would be selective in its responsiveness and focus on particular immunodominant proteins: the so-called immunological homunculus (Cohen and Young, 1991; Cohen, 2007). Hsp were thus postulated to be such proteins. However, the regulatory capacity of Hsp could not be completely explained by immunodominance and homology between bacterial- and self-Hsp. This was demonstrated in studies using the adjuvant-induced arthritis model, in which Hsps, but not other highly immunogenic and conserved proteins of bacterial origin, were found to suppress disease development (Prakken et al., 2001). So, which additional features of Hsp would endow them with the capacity to suppress inflammatory responses? Along the years, different groups have collected evidence on Hsp70 involvement in innate and adaptive immune responses.

\section{INNATE IMMUNE CELL MODULATION BY}

\section{Hsp70 - EXTRACELLULAR Hsp70}

The idea that Hsp70 could modulate innate cell function comes from studies that analyzed the interaction of Hsp70, either delivered extracellularly or present in the outer cell membrane/exosomes, with receptors on cells such as monocytes, dendritic cells (DCs) and myeloid-derived suppressor cells (MDSCs). This notion was surprising initially, because Hsp70 was then believed to be an intracellular chaperone. However, studies by Hightower and Guidon Jr. (1989) revealed that Hsp70 could be released from cells, in a mechanism that was independent of blockage of secretory pathways. A series of studies followed, revealing that soluble Hsp70 could be measured in the serum of both healthy and diseased individuals (Pockley et al., 1998); and that this extracellular Hsp70 could be either actively secreted by a non-classical pathway, or released from dying cells, review in De Maio (2011).

Two new functions were then reported for extracellular Hsp70. One study demonstrated that (mammalian) Hsp70-peptide complexes purified from MethA sarcomas could lead to priming of cytotoxic $\mathrm{T}$ cell (CTL) responses against these tumors (Udono and Srivastava, 1993). That meant that Hsp70 could probably bind to a membrane receptor in antigen-presenting cells (APCs), and get access to the endogenous route of antigen processing and presentation in MHC class I - i.e., cross-priming. A different group later reported that human Hsp70 could bind to and activate human monocytes, promoting the secretion of inflammatory cytokines, such as TNF- $\alpha$, IL-1 $\beta$, and IL-6 (Asea et al., 2000a). Different groups went on to corroborate the findings of the crosspriming abilities of Hsp70 (Delneste et al., 2002; Kammerer et al., 2002; Ueda et al., 2004). However, the findings on the induction of pro-inflammatory cytokines were disputed (Gao and Tsan, 2004) when the removal of contaminating endotoxin of the recombinant preparations of human Hsp70 abrogated the induction of TNF- $\alpha$ by this protein. Hsp70 is a molecule with high affinity for hydrophobic moieties (Tsan and Gao, 2009) and the efficient removal of LPS and lipid-like contaminants from preparations of Hsp70 proved to be a challenge for those working with this protein. It is thus very likely that the ability of Hsp70 to bind cell surface receptors (see below) and be internalized, activating antigen presentation, which has been verified by independent groups, is independent of the induction of inflammatory cytokines by this protein, which, to this date, is still disputed.

The removal of contaminating endotoxin and lipopeptides by treatment with Triton X-114, a detergent, revealed that soluble Hsp70 had, in fact, anti-inflammatory properties. It was demonstrated that TB-Hsp70 could modulate cytokine production in blood and synovial cells of arthritis patients. In vitro treatment with endotoxin-free TB-Hsp70 for $48 \mathrm{~h}$ induced IL-10 production in peripheral blood mononuclear cells (PBMCs) from rheumatoid arthritis (RA) and reactive arthritis (ReA) patients as well as in normal controls PBMCs (Detanico et al., 2004). Concomitantly, PBMCs from these patients downregulated IFN- $\gamma$ production (900-fold for RA patients and 750-fold for ReA patients when compared with untreated cells) and up-regulated IL-10 production (900-fold for RA patients and 500-fold for ReA patients). In addition, synovial cells incubated with TB-Hsp70 for $48 \mathrm{~h}$ showed a reversal of the inflammatory profile, with an induction of IL-10 [a 4.9-fold increase when compared with cells treated with bovine serum albumin (BSA) and LPS], correlating with a decrease in TNF- $\alpha$ and IFN- $\gamma$ production. Synovial monocytes from the arthritis patients were the major source of IL-10 induced by TB-Hsp70. In accordance with these findings, 
Luo et al. (2008) demonstrated that human Hsp70 downregulated in a concentration-dependent manner the TNF- $\alpha$-induced production of pro-inflammatory mediators IL-6, IL-8, and MCP-1 in RA fibroblast-like synoviocytes when compared with OVA-treated cells. Thus, Hsp70, both bacterial and human, were shown to be associated with a protective phenotype in arthritis, corroborating the initial findings in adjuvant arthritis.

TB-Hsp70 could also modulate cytokine production in DCs. These cells provide a link between innate and adaptive responses, by presenting antigen to $\mathrm{T}$ cells, activating them, and shaping their differentiation into effector phenotypes (Heath and Carbone, 2009; Watowich and Liu, 2010). Production of IL-12 by DCs leads to a Th1 program of differentiation for the antigen-specific $\mathrm{CD}^{+} \mathrm{T}$ cells, while IL-4 production induces a Th2 phenotype. Tolerogenic DCs, however, are characterized by low production of pro-inflammatory cytokines and high production of antiinflammatory cytokines. It has been shown that cells expressing low levels of both MHC class II and T cell co-stimulatory molecules - such as CD80 and CD86, and that do or do not produce IL-10 and TGF- $\beta$, can be tolerogenic (Steinman et al., 2003; Rutella et al., 2006; Morelli and Thomson, 2007).

LPS-free TB-Hsp70 blocked the in vitro differentiation of DCs from bone marrow precursors. When murine bone marrow DCs (BMDCs) were treated with TB-Hsp70 for 24 or $48 \mathrm{~h}$, an inhibition of maturation characterized by a failure to acquire $\mathrm{MHC}$ class II and CD86 expression was observed. TB-Hsp70-treated BMDCs had an eightfold increase in IL-10 production when compared with dexamethasone treated cells and produced 1,200-fold less TNF- $\alpha$ than LPS stimulated cells after $48 \mathrm{~h}$ of culture (Motta et al., 2007), suggesting not all transcription was inhibited in the treated BMDCs. More recently, a different group demonstrated that soluble inducible human Hsp70 (now known as HSPA1A) can also induce a regulatory phenotype in monocyte-derived DCs (MoDCs; Stocki et al., 2012). They tested three preparations of Hsp70, two commercial ones, with high or medium endotoxin levels, and one other with very low endotoxin levels. Only the Hsp70 preparations with high and medium endotoxin levels induced maturation of MoDCs in culture. The very low endotoxin level Hsp70, however, inhibited the maturation of MoDCs and reduced the capacity of those cells of stimulating allogeneic $\mathrm{T}$ cell proliferation. Together, these results indicated that both TB-Hsp70 and human Hsp70 produced a tolerogenic phenotype in DCs, provided that LPS contamination was eliminated.

These findings in DC have an important implication for a regulatory role of soluble forms of Hsp70. Tolerogenic DCs are known to contribute to the creation of a "suppressive environment" facilitating the peripheral generation of peripheral Tregs. Tregs play a crucial role in suppressing the excessive effector immune response that is harmful to the host (Sakaguchi et al., 2008). These cells can be divided into two subphenotypes. The first one is the Foxp3expressing Tregs that develop in the thymus (nTregs; Feuerer et al., 2009). The second are the cells that can be induced in peripheral sites when given appropriate signals by the APCs (iTregs; Shevach, 2006). Tregs produce IL-10 or TGF- $\beta$, sometimes both, and actively suppress non-Treg proliferation (Vignali et al., 2008). Low levels of antigen presentation coupled to low co-stimulation have been linked to the differentiation of induced Tregs (iTregs; Jenkins et al., 1990; Steinman et al., 2000; Long et al., 2011). Thus, it was possible that, by modulating the APCs, Hsp70 could lead to the induction of Tregs in the periphery.

Confirming this prediction, soluble TB-Hsp70 was demonstrated to inhibit acute allograft rejection (Borges et al., 2010). When $\mathrm{C} 57 \mathrm{Bl} / 6$ tumor cells or skin sections were pre-incubated in a solution with endotoxin-free TB-Hsp70 and then grafted onto a BALB/c host, the tumor cells formed a solid tumor, and skin rejection was delayed for 7-10 days, compared to controls. This effect was abrogated by depletion of Tregs, which were shown to infiltrate the accepted grafts. Interestingly, when soluble TBHsp70 was injected subcutaneously, this led to an increase in $\mathrm{CD}^{+}{ }^{+} \mathrm{CD} 25^{+}$Foxp $^{+}$cells in the draining lymph node, which correlated to a diminished proliferation of lymph node cells in response to a $\mathrm{T}$ cell mitogen. The conclusion was that one single pretreatment with TB-Hsp70 could inhibit a powerful in vivo inflammatory process, and this correlated with the presence of Tregs.

The possibility that Hsp70 and Tregs are intimately linked is discussed in detail in the second part of this article (adaptive immunity). In the meantime, we wish discuss one more evidence that Hsp70 can act as an immunosuppressant - and this is related to another discovery, namely that Hsp70 could localize in membranes.

It was shown that Hsp70 (Vega et al., 2008), similarly to Hsc70 (Arispe and De Maio, 2000) could integrate into an artificial lipid bilayer, opening cationic conductance channels, and this ability was associated with the presence of phosphatidylserine (PS; Arispe et al., 2004). Other sphingolipids, such as globotriaosylceramide, have also been reported to enhance Hsp70 insertion into membranes (Gehrmann et al., 2008). This supported previous reports that Hsp70 could be found in the membrane of tumors (Ferrarini et al., 1992; Multhoff et al., 1995). Hsp70 was not simply associated with a receptor in the membrane, but rather inserted, because it could not be eluted by acid washes, or Triton X-1000 (Vega et al., 2008) and because only one antibody, recognizing a part of the C-terminus, but not antibodies that would recognize the N-terminus, would detect it (Botzler et al., 1998). The presence of Hsp70 in membranes of cells or exosomes of tumors presented one more way of extracellular interactions of Hsp70.

Myeloid-derived suppressor cells are a different, heterogeneous population of cells that are expanded during cancer, inflammation, and infection, with a remarkable ability to suppress $\mathrm{T}$ cell responses (Gabrilovich and Nagaraj, 2009). Chalmin et al. (2010) demonstrated, in mice and humans, that membrane-associated Hsp70 found in tumor-derived exosomes (TDEs) restrained tumor immune surveillance by promoting MDSCs suppressive functions. It was demonstrated that TDEs, contained in the tumor cell supernatant of three tumor cell lines, could mediate $\mathrm{T}$ cell-dependent immunosuppressive functions of MDSCs. The authors identified that the factor present on the TDEs that induced MDSCs activation was the inducible Hsp70 (HSPA1A) expressed on TDE cell surface. Hsp70 was only present on exosomal fractions, not in other microparticles. These findings indicated that immunomodulatory effects of tumor cells include their potential of inducing functional MDSCs by releasing exosomes expressing Hsp70. 


\section{Hsp70 PUTATIVE RECEPTORS AND RESPECTIVE SIGNALING PATHWAYS}

Many studies asked the question of how would cells perceive the presence of extracellular Hsp. CD14 (Asea et al., 2000b), and Toll-like receptors (TLRs) 2 and 4 (Asea et al., 2002) were first proposed to be receptors for soluble extracellular human Hsp70 - and this was, as discussed above, disputed due to the contamination issue. CD40 (Wang et al., 2001) was then proposed as a receptor for mammalian Hsp70, however a different study (Binder, 2009) refuted this idea, demonstrating that Hsp70 would still bind to cells in CD40 knockout mice. CD91 (Basu et al., 2001) and LOX1 (Delneste et al., 2002), two scavenger receptors, were shown to bind Hsp70-antigen complexes, increasing cross-presentation and eliciting a protective immune response against antigen-expressing tumor cells in vivo. Floto et al. (2006) suggested that TB-Hsp70 promoted DC aggregation, immune synapse formation between DCs and T cells, and an effector immune response the signaling through the CCR5 chemokine receptor. All these different results generated great confusion. A consistent finding among studies was the ability of extracellular Hsp70 to be internalized and interact with antigen presentation routes, inducing $\mathrm{T}$ cell responses to the peptides that associated with this protein. TLRs and CD40 are signaling receptors, rather than endocytic receptors. Scavenger receptors and lectin-like receptors are endocytic receptors, and the signaling events downstream binding and internalization that follows binding are not fully characterized.

A thorough study transfected Chinese hamster ovary (CHO) cells with cDNAs expressing each of these putative receptors, as well as other scavenger receptors and lectins, and studied their interaction with mammalian extracellular Hsp70 (Theriault et al., 2005). The authors verified no binding or internalization of Hsp70 with cells expressing TLR2, TLR4, CD40, or CD91. In a followup study, they used the same approach focusing on scavenger receptors (Theriault et al., 2006). They demonstrated that LOX-1, SREC-1, and FEEL-1 bind and internalize Hsp70. However, different forms of Hsp70 (peptide bound or ATP bound) interacted with each of these receptors with different affinities. In summary, while binding to signaling receptors was refuted by more than one study, different groups provided evidence for scavenger receptors as the likely receptors for extracellular Hsp70.

\section{SIGNALING ROUTES ACTIVATED BY Hsp70}

If extracellular Hsp70 indeed interacts with membrane-bound receptors, will it activate signaling pathways associated with these receptors? Few studies approached this issue.

Mitogen-activated protein (MAP) kinase cascade is one of the most ancient and evolutionarily conserved signaling pathways, which is also important for many processes in immune responses (Dong et al., 2002). TDE-associated Hsp70 was found to mediate the suppressive activity of the MDSCs via activation of STAT3 and ERK (Chalmin et al., 2010). An ERK-dependent route for IL-10 production by different immune system cells upon TLR stimulation has been described (Saraiva and O'Garra, 2010). It has been suggested that some TLR2 agonists are good inducers of IL-10 production (Dillon et al., 2006; Manicassamy et al., 2009; Saraiva and O'Garra, 2010; Yamazaki et al., 2011). It is an interesting feature of TLR2 that, depending on the nature of the ligand and the population of target cells, it can mediate either inflammatory or anti-inflammatory responses to the same infectious organism (Dillon et al., 2006; Frodermann et al., 2011), and the anti-inflammatory response is mediated by IL- 10 .

IL-10 is the main anti-inflammatory and immunosuppressive cytokine (Moore et al., 2001). However, depending on the situation, it can exert a pro-inflammatory role like in lupus erythematosus (Bussolati et al., 2000; Sharif et al., 2004). It has been suggested that type I interferons regulate the balance between antiand pro-inflammatory role of IL-10 (Sharif et al., 2004). In monocytes of patients with systemic lupus erythematosus (SLE), it was demonstrated that IL-10 can stimulate production of plateletactivating factor (PAF) and this production was correlated with disease severity (Bussolati et al., 2000).

IL-10 production of by DCs stimulated via TLRs is diminished in presence of selective ERK inhibitors (Yi et al., 2002; Dillon et al., 2004; Kaiser et al., 2009) or in ERK-deficient cells (Agrawal et al., 2006). Besides, differences in IL-10 production by macrophages, myeloid DCs, and plasmacytoid DCs are correlated with different levels of ERK activation in these cells (Saraiva and O'Garra, 2010). Borges et al. (in preparation) observed that BMDCs treated with TB-Hsp70 showed a higher expression of phospho-ERK when compared with unstimulated cells, and inhibition of ERK expression with the specific ERK inhibitor PD98059 blocked IL-10 production upon incubation with Hsp70.

STAT3 is associated with IL-10 production and tolerance (Barton, 2006; Dhingra et al., 2011). Also, IL-10R recruits and activates JNK1-STAT3 pathway (Murray, 2006). In contrast, STAT3 can be activated by pro-inflammatory cytokines like IL-6, through IL-6R (Murray, 2007) and Oncostatin M (Halfter et al., 1999). Despite this duality in STAT3 activation, this transcription factor may be activated after IL-10 release induced by TB-Hsp70.

Based on this, we propose a model in which extracellular Hsp70 could regulate innate immune cell function, binding to cell surface receptors (a scavenger or lectin-like receptor), signaling through TLR2 via ERK to induce IL-10 production, resulting in an anti-inflammatory response. This model is depicted in Figure 1.

Is it possible to reconcile this model with what has been observed for the cross-priming and pro-inflammatory roles described for this protein? We believe that the next studies should test the possibility that extracellular Hsp70, upon binding to lectinlike or scavenger receptors, uses associated receptors to signal. It is possible that depending on the form of Hsp70 (associated with peptide; with membranes; with nucleotides; peptide-free) it will associate with a different receptor. Another issue that has to be considered is that, while in bacteria, Hsp70 comes from one gene, in mammals, there may be at least eight genes that code for Hsp70 (Kampinga et al., 2009). Bulk preparations of mammalian Hsp70 from cells contain not only the inducible, HSPA1A, but products from other genes as well. And this may also influence the outcome of the experiment. Finally, binding and internalization, followed by antigen presentation, may lead to inflammatory as well as to regulatory responses, depending on which receptor is engaged, as demonstrated in a recent study (Li et al., 2012). The authors verified that targeting an antigen to LOX-1 or DC-ASGPR on the surface of DCs led to internalization and cross-presentation of 


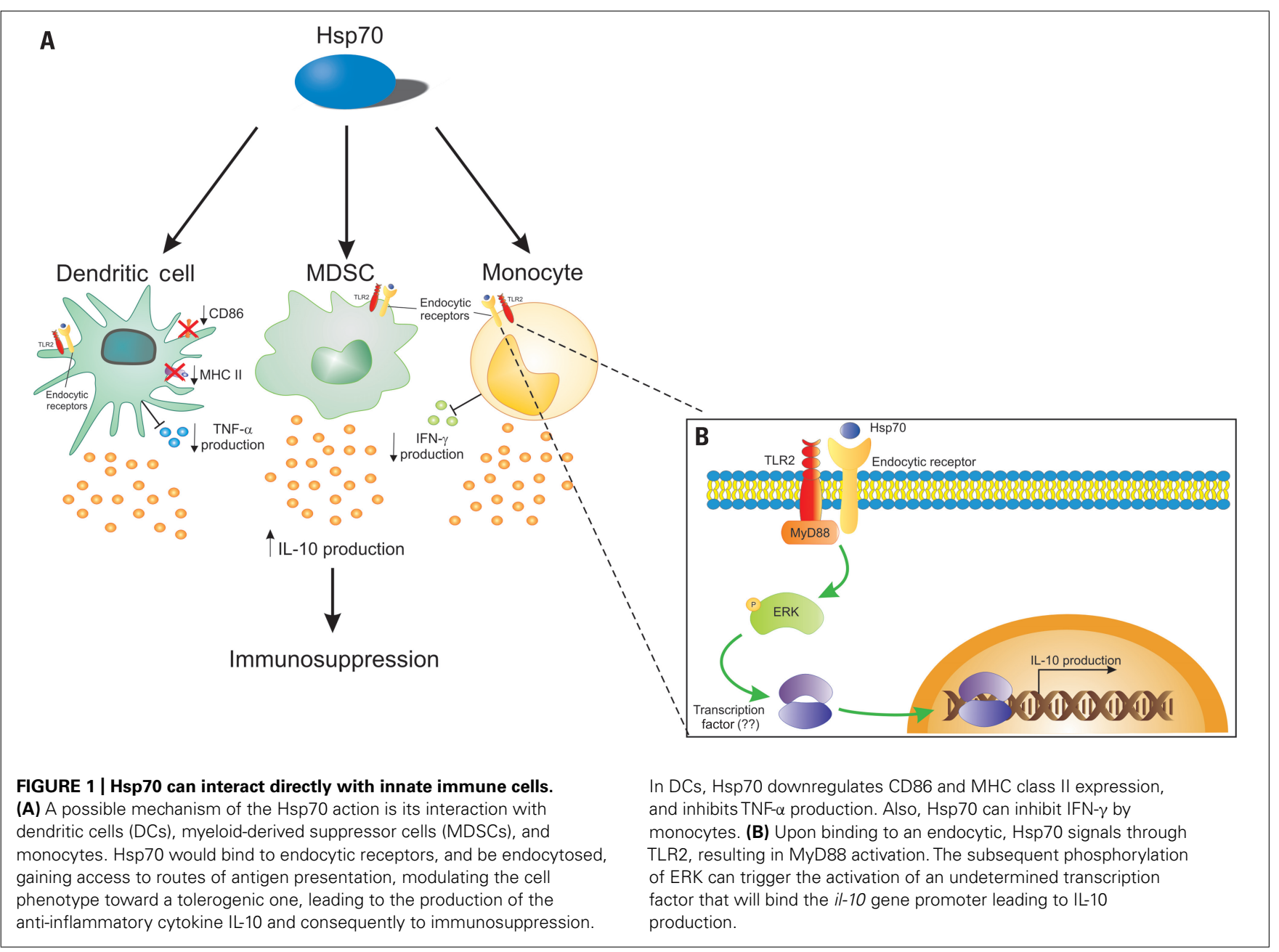

the antigen. However, while targeting to LOX-1 resulted in INFgamma producing $\mathrm{T}$ cells, targeting to DC-ASGPR resulted in IL-10 producing CD4 $\mathrm{T}$ cells. Thus, it is possible that, depending on the form of extracellular Hsp70 and the target cell/tissue microenvironment, different outcomes may ensue. If this possibility is verified experimentally, that would in part explain some of the conflicting results previously discussed here. We are now left with the challenge to test these possibilities in order to elucidate the whole potential of Hsp70 as an immunomodulatory agent.

\section{ADAPTIVE IMMUNITY REGULATION BY Hsp70}

Besides the innate effects discussed above, several adaptive immunity associated mechanisms have been proposed for induction of Hsp-specific Tregs under physiological conditions.

The role of Hsp70 in adaptive immunity to mediate suppression through Tregs could be related to presentation of Hsp70 peptides, or to the modulation of the innate environment as described in the previous section, leading to the induction of Tregs.

The presentation of Hsp70 peptides in MHC molecules could result either from overexpression of endogenous Hsp70 in situations of physiological stress, or from endocytosis of extracellular Hsp; In response to physiological stress, intracellular levels of Hsp70 will rise in the stressed cells which can lead to presentation of Hsp peptides on MHC class I via the default MHC loading route for cytosolic proteins. This pathway includes degradation of the protein by the proteasome, transporter associated with antigen presentation (TAP) mediated translocation to the endoplasmic reticulum and subsequent loading of the peptides on MHC class I molecules (Neefjes et al., 2011). As will be discussed in more detail below, it is now becoming clear that via autophagy, intracellular Hsp can also be loaded on MHC class II molecules. Peptides derived from extracellular Hsp (pathogen-associated or secreted endogenous Hsp) can be presented via endocytic pathways by MHC class II molecules on APCs or on non-APCs upon stimulation with factors like IFN $\gamma$.

The mechanisms leading to production of Hsp-specific Treg can be manifold. Continuous encounter of bacterial-Hsp, in mucosal surfaces such as the gut can be a way to induce bacterial-Hspspecific Treg, contributing to Hsp-specific mucosal tolerance (van Eden et al., 2005, 2007). Another possibility is the up-regulation of self-Hsp on non-professional APCs in response to various forms of stress in tissues. In the gut lamina propria of many species, MHC class II is also found to be present on non-professional APCs (Stokes et al., 1996). In addition, the inflammatory mediator IFN- $\gamma$ is known to induce MHC class II in various cell types. Thus, MHC class II presentation of Hsp fragments in the absence 
of proper co-stimulation may add to the production of tolerogenic or regulatory $\mathrm{T}$ cell responses. In addition, presentation of self-Hsp70 conserved peptides in presence of TGF- $\beta$ (Sela et al., 2011) could lead to Treg induction and/or expansion (Rosenblum etal., 2011). Also, because some self-Hsp70 peptides are not completely identical to their bacterial homolog peptides, such presented self-peptides could function as altered peptide ligands for bacterial-Hsp-specific cells leading to induction of a partially agonistic and therefore downmodulated T cell response (Wauben et al., 1993). Finally, induction of Treg might be reinforced by the increased levels of the immunoregulatory cytokine IL-10, induced upon stress in multiple tissues (Stordeur and Goldman, 1998).

\section{AUTOPHAGY, LOADING Hsp PEPTIDES ON MHC CLASS II}

To activate $\mathrm{CD}^{+}{ }^{+} \mathrm{T}$ cells, peptides should be presented by MHC class II molecules. Cytosolic proteins, like Hsp70, are by default loaded on MHC class I molecules while extracellular proteins will be presented on MHC class II. Thus, another fundamental question can be raised; how do Hsp peptides end up to become presented by MHC class II? The distinct localization between MHC class I and MHC class II loading pathways has been proven incorrect because cytosolic proteins have been eluted from MHC class II and vice versa (Schmid et al., 2007). Autophagy has been initially found as a process to sustain metabolic fitness during food deprivation through bulk protein degradation (Kuma et al., 2004). The role of autophagy in the immune system is only now becoming clear (Schmid and Munz, 2007; Munz, 2009). Two pathways can result in loading of intracellular peptides on MHC class II. First, intracellular proteins can be incorporated in autophagosomes that subsequently fuse with lysosomes for degradation of their cargo (macroautophagy). In addition, cytosolic proteins can be transported via LAMP2a directly into the lysosome (chaperone mediated autophagy; Munz, 2006; Schmid et al., 2007; Strawbridge and Blum, 2007). Recently, the role of autophagy in loading Hsp70 peptides has been described; in human HLA$\mathrm{DR}^{+} \mathrm{B}$ cells a striking increase of especially Hsp70 peptides was eluted from HLA-DR4 upon induction of autophagy by amino acid deprivation (Dengjel et al., 2005). Autophagy induction coincided with elevated Hsp70 mRNA levels. In other words, especially under conditions of cell stress, fragments of Hsp70 will be presented on APCs to $\mathrm{T}$ cells, possibly initiating a regulatory $\mathrm{T}$ cell response.

\section{PHENOTYPE OF Hsp-SPECIFIC Treg}

The phenotype of Hsp-specific Treg has not been studied in detail. However, since Hsp-specific T cells have been observed in cord blood, some of them will probably be thymus derived $\mathrm{CD}^{+}{ }^{+} \mathrm{CD} 25^{+}$Foxp3 $^{+}$natural Treg (Sakaguchi et al., 1995; Tang and Bluestone, 2008). Also, Hsp-specific Treg can be induced in the periphery, which potentially leads to induction of several induced Treg subsets. For example, Foxp $3^{-} \operatorname{Tr} 1$ cells, which are induced by repetitive stimulation with antigen in the presence of IL-10 (Groux et al., 1997; Roncarolo and Battaglia, 2007). Alternatively, mucosal exposure of Hsp can produce iTregs, expressing a $\mathrm{CD} 4{ }^{+} \mathrm{CD} 25^{+}$Foxp $3^{+}$phenotype (Chen et al., 1994; Weiner, 2001). Or, conversion of naïve CD $4^{+} \mathrm{CD} 25$-Foxp $3^{-}$cells into induced $\mathrm{CD} 4^{+} \mathrm{CD} 25^{+}$Foxp $^{+}$can occur in the presence of IL- 2 and TGF- $\beta$ at low levels of pro-inflammatory cytokines (Horwitz et al., 2008).

The phenotype of the Hsp-specific Treg may depend on the exposure route. Intraperitoneal (i.p.) immunization with endotoxin-free TB-Hsp70 or OVA as a control resulted in $\mathrm{CD} 4{ }^{+} \mathrm{CD} 25^{+} \mathrm{T}$ cells from $\mathrm{Hsp} 70$ immunized mice expressing slightly enhanced levels of regulatory cytokine IL-10, but not increasingly expression of Foxp3 (Wieten et al., 2009a). In contrast, in a study in a mouse atherosclerosis model, oral Hsp administration increased Foxp3 expression (van Puijvelde et al., 2007). Enhanced Foxp3 expression, both systemically in the spleen and locally in the inflamed joint, was also found upon up-regulation of endogenous Hsp70 in Peyer's patches of carvacrol (a co-inducer of Hsp70) fed mice (Wieten et al., 2010). The finding that Foxp3 levels were increased in cells obtained from joint synovial fluid suggested that induced Treg could have actually migrated to the site of inflammation.

In a recent study, after local injection of whole TB-Hsp70, a higher percentage of $\mathrm{CD} 4^{+} \mathrm{CD} 25^{+}$Foxp $3^{+}$cells in draining lymph nodes compared with local injection with OVA was observed. Moreover, TB-Hsp70 inhibition of lymph node cell proliferation was superior to the inhibition induced by dexamethasone after PHA stimulation. The authors also observed that inhibition of acute rejection induced by TB-Hsp70 was dependent on $\mathrm{CD} 4{ }^{+} \mathrm{CD} 25^{+} \mathrm{T}$ cells in a skin allograft model (Borges et al., 2010).

To study the phenotype of Hsp-specific Treg in more detail, the expression of the transcription factor Helios in Tregs elicited by Hsp70 treatment, to verify if they are nTregs or iTregs (Thornton et al., 2010), since peripherally induced Tregs do not usually express this molecule. It will also be interesting to see if $\mathrm{T}$ cells found at the site of inflammation are Hsp70 specific, and if they indeed express special homing receptors. Future studies should tell us the relative proportions of nTregs and iTregs in Hsp70specific Tregs, as well as what are the mechanisms by which they can mediate suppression in each of these models.

\section{SUPPRESSIVE MECHANISM OF Hsp-SPECIFIC Treg}

Hsp-specific Treg will probably use similar suppressive mechanisms as other antigen-specific Treg, like the production of anti-inflammatory cytokines, cell contact dependent suppression or killing of effector T cells and conversion of APC into a tolerogenic state (Vignali et al., 2008). Most Treg subsets use IL-10 for suppression (Bluestone, 2005). It has been recently demonstrated that Treg IL-10 is important for local responses, and not for the systemic suppression of inflammation (Rubtsov et al., 2008). In previous studies, we showed that cross-reactive Hsp-specific T cell responses coincided with the production of IL-10 (Anderton et al., 1995; Wendling et al., 2000; Prakken et al., 2001). Subcutaneous injection of soluble TB-Hsp70 increased IL-10 production and the number of Tregs in draining lymph nodes when compared with OVA injection (Borges et al., 2010). Moreover, while addressing the role of IL-10 in modulation of Proteoglycan-induced arthritis (PGIA) upon i.p. immunization with TB-Hsp70 and after nasal administration of Hsp70 peptides, it was observed that both treatment strategies enhanced Hsp70-specific T cell proliferation and IL-10 production. TB-Hsp70 immunization failed to rescue IL-10 
deficient mice from PGIA development. In both wild type and IL10 deficient mice, Hsp70-specific T cell responses were found, but only in wild type mice these responses suppressed arthritis (Wieten et al., 2009a). In addition, increased PG-specific T cell proliferation, IFN- $\gamma$ and IL-10 production were found in wild type, but not in IL-10 deficient mice. This illustrates that Hsp70 immunization also modified the PG response to a more anti-inflammatory response. It is therefore possible that Hsp70induced Tregs generated a tolerogenic micro-milieu by their cytokine production that enabled the outgrowth of new Tregs with antigen specificities beyond Hsp and that IL-10 was required for this effect.

These findings emphasize that Hsp-specific Tregs use mechanisms of infectious tolerance for modulation of inflammation. This has been shown before in transplantation (Qin et al., 1993; Borges et al., 2010), type-1 diabetes (Tarbell et al., 2007), and experimental autoimmune encephalomyelitis (EAE; Mekala et al., 2005) models. Besides IL-10, the role of other cytokines associated with Tregs, like IL-35 has not been addressed but might be relevant.

\section{HOW IMPORTANT IS STRESS-INDUCED Hsp EXPRESSION?}

Hsp expression is up-regulated in virtually every inflammatory condition. Also in autoimmune disease this has been reported; enhanced expression of Hsp60 has been shown in synovial and mononuclear cells of juvenile idiopathic arthritis (JIA) patients (Boog et al., 1992; de Graeff-Meeder etal., 1995). In addition, increased expression of inducible Hsp70 and HSF1 has been shown in the inflamed joint of RA patients (Schett et al., 1998). This has also been seen for BiP, an ER restricted Hsp70 family member (Blass et al., 2001) and interestingly enhanced expression in RA synovium was also seen for the constitutive Hsc70 (Schick et al., 2004).

As mentioned before, stress-induced Hsp expression has been proposed to be important for induction, maintenance, and activation of Hsp-specific Treg. If indeed so, reduced expression of Hsp - like with aging, as also depicted in Figure 2, where a reduced HSF activity leads to a relatively poor capacity to up-regulate Hsp (Rao et al., 1999; Njemini et al., 2003) - can be expected to influence Hsp mediated immune homeostasis and therefore might contribute to development of chronic inflammatory diseases. In fact, Hsp70 polymorphisms have been associated with inflammatory or autoimmune diseases such as Crohn's disease (Debler et al., 2003), Alzheimer's disease (Clarimon et al., 2003), pancreatitis (Balog et al., 2005) and with development of graft versus host disease upon allogeneic hematopoietic stem cell transplantation (Bogunia-Kubik and Lange, 2005).

Decreased Hsp expression has been observed in several immune disorders. A low Hsp70 response has also been described in a subtype of Biobreeding (BB) rats with a high susceptibility for development of autoimmune (Bellmann et al., 1997). Similar results have been found in human PBMC from patients with newly diagnosed type-1 diabetes. In that study, stress responses were found to become re-established again in patients with longstanding diabetes, more than 8 months after disease manifestation. So, defective Hsp70 induction coincided with beta cell directed inflammatory activity, and seemed modulated by pro-inflammatory cytokines rather than metabolic factors (Burkart et al., 2008).

To amplify stress-induced Hsp70 expression, a study tested multiple food-derived compounds for their effect on Hsp70 expression (Wieten et al., 2009b). One of the compounds, carvacrol, was identified as a potent enhancer of stress-induced Hsp70 both in vitro and in vivo. Also in vivo, intragastric (i.g.) gavage of carvacrol enhanced Hsp70 expression in Peyer's patches (Wieten et al., 2010). Carvacrol was used to boost Hsp levels in APCs and this enhanced Hsp-specific T cell hybridoma activation. We also addressed the immunomodulatory potential of carvacrol in vivo and found that i.g. carvacrol treatment specifically boosted Hsp70specific $\mathrm{T}$ cell responses. The finding that adoptive transfer of $\mathrm{T}$ cells, isolated from carvacrol treated donor mice, suppressed PGIA, were indicative of the induction of Treg.

The above mentioned findings suggested that the immune system can recognize and react on altered expression of these proteins.

\section{PERSPECTIVES}

Hsp expression or Hsp-specific T cell responses have been positively associated with a better disease prognosis in several inflammatory conditions (de Graeff-Meeder et al., 1991; de Kleer et al., 2003). In addition, the immunosuppressive action of Hsp has been demonstrated in multiple rodent disease models. So, it is attractive to speculate that simply enhancing Hsp mediated immunoregulation in either way could be used as therapy.

Apparently, this is oversimplified. Depending on multiple factors such as disease etiology and inflammatory status, patient age and genetic background, difficulties will be encountered. In general, defects in for example positive or negative selection in the thymus, IL- 2 production by effector T cells or IL-10 or TGF- $\beta$ production by Tregs can lead to loss of peripheral tolerance as a result of decreased $\mathrm{T}$ cell numbers or functioning (Brusko et al., 2008). Some of these defects might also influence Hsp-specific Treg. For example, the findings that Hsp70-induced suppression of arthritis failed in the absence of IL-10 (Wieten et al., 2009a), illustrated that defects in IL-10 production will also influence Hspspecific Treg. Furthermore, as disease progresses, severe ongoing inflammation has been described to obstruct the effectiveness of antigen-specific Tregs (Valencia et al., 2006; Peluso et al., 2007). It is currently not known if Hsp-specific Treg can also be hampered by ongoing inflammation. Recent experiments performed by us (Lotte Wieten, Martijn J. C. van Herwijnen, Femke Broere, Ruurd van der Zee, and Willem van Eden) have indicated that this is not the case, however. Transfer of Hsp70 peptide-induced Tregs were found to suppress ongoing experimental arthritis (van Herwijnen et al., in preparation). Recently, it has been reported that iTreg but not natural Treg can convert into Th17 cells after exposure to IL-6 and TGF- $\beta$ (Horwitz et al., 2008). Besides Th1 cells, Th17 cells are major pathogenic effector cells in many autoimmune diseases. Whether Hsp-specific Treg can convert into Th17 cells has not been studied, but if so, timing and route of boosting the Hsp response could be important to avoid exacerbation of disease instead of induction of regulation.

Earlier studies have emphasized the pro-inflammatory nature of stress proteins such as the Hsp70 family members. In this 


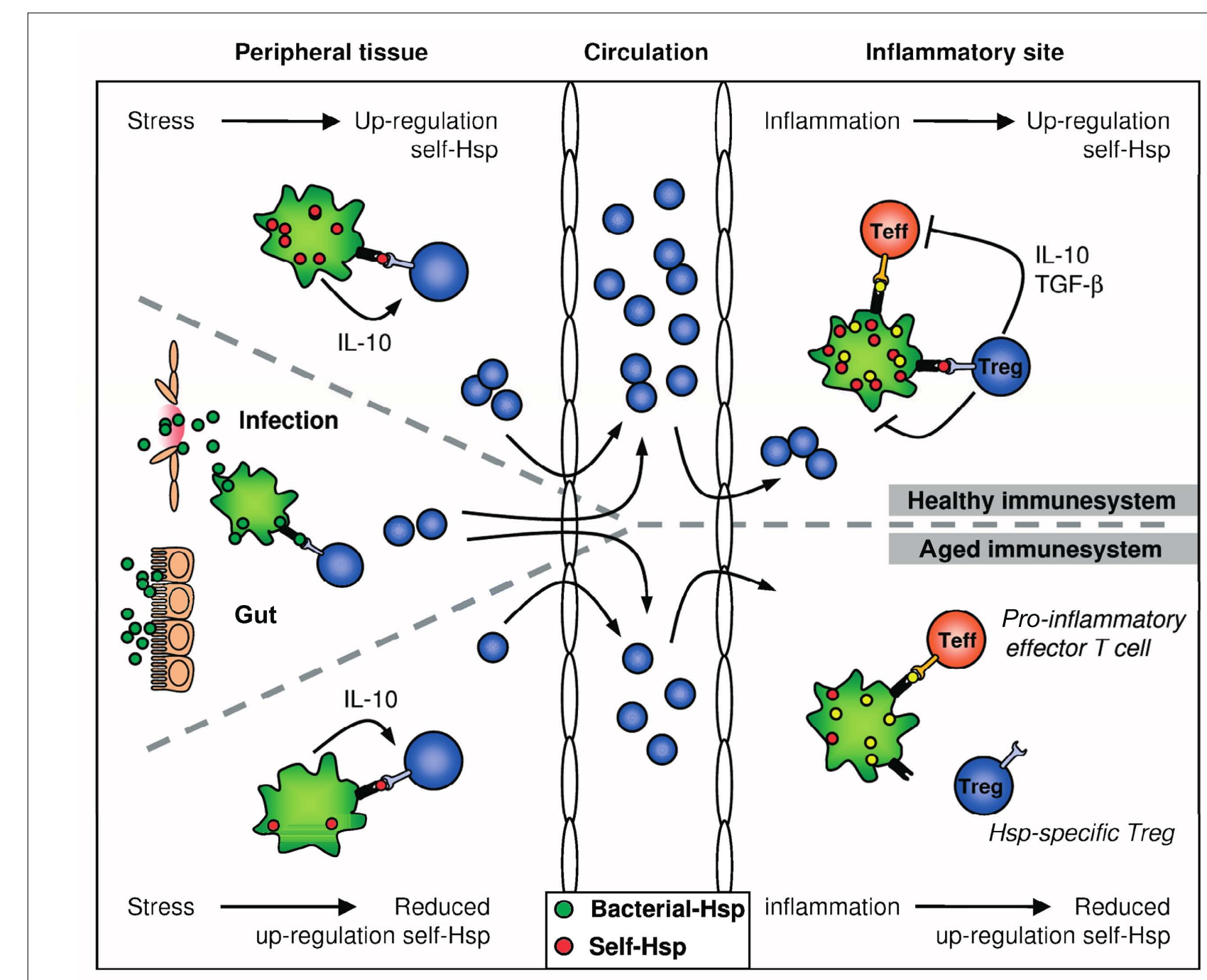

FIGURE 2 | Hsp-specific immunoregulation in the healthy and aged immune system. Self-Hsp-specific T cells reside in the circulation after escape from central tolerance in the thymus. Since Hsp are highly conserved, these self-Hsp-specific T cells can cross-recognize bacterial-Hsp. This T cell population can be expanded after exposure to bacterial-Hsp at mucosal surfaces like the gut or during infection. At mucosal surfaces, these T cells will be directed toward a regulatory phenotype through mechanisms of mucosal tolerance. In addition, Treg induction and maintenance will be promoted by stress-induced Hsp expression in peripheral tissues, because up-regulation of self-Hsp and presentation of Hsp peptides by MHC class II can occur in the absence of co-stimulation. Treg induction will be enhanced by IL-10 produced in response to stress. Furthermore, self-Hsp peptides can function as altered peptide ligands for bacterial-Hsp-specific T cells. During inflammation, Hsp will be induced and presented on professional APCs at the inflammatory site, leading to full activation of Hsp-specific Treg and local dampening ongoing inflammation. In the aged immune system,

stress-induced Hsp expression is decreased. Therefore, reduced Hsp inducibility will probably influence both the induction of Hsp-specific Treg in the periphery and their activation during inflammation. Ultimately, this could result in reduced Treg numbers and function. sense, they were often mentioned as prime examples of socalled DAMPs or damage-associated molecular patterns. It is possible that contaminating microbial components present in partially purified recombinant proteins used in the experiments have contributed to this (Bausinger et al., 2002; Gao and Tsan, 2004; Motta etal., 2007). Besides this, there are other arguments to make against a pro-inflammatory role of Hsp (Broere et al., 2011). As discussed here above, experimental evidence in favor of an immunomodulatory role for Hsp70 is accumulating and therefore Hsp70's immunosuppressive potential seems to constitute a real phenomenon. A more detailed characterization of the molecular pathways activated by Hsp70 in different cell subpopulations is needed. Such studies will allow us to understand and maximize the use of Hsp70 as an anti-inflammatory agent.

\section{ACKNOWLEDGMENTS}

Thiago J. Borges and Cristina Bonorino want to thank Dr. Bruno Paim for his support with the figures and CNPq and FINEP for the financial support. This work of Lotte Wieten, Martijn J. C. van Herwijnen, Femke Broere, Ruurd van der Zee, and Willem van Eden was supported by grants of IOP Genomics project nr IGE07004, the European Union FP7 TOLERAGE: HEALTH-F42008-20215 and the Dutch Arthritis Association. 


\section{REFERENCES}

Aalberse, J. A., Kapitein, B., de Roock, S., Klein, M. R., de Jager, W., van der Zee, R., Hoekstra, M. O., van Wijk, F., and Prakken, B. J. (2011). Cord blood CD4 $\mathrm{T}$ cells respond to self heat shock protein 60 (HSP60). PLoS ONE 6, e24119. doi: 10.1371/journal. pone.0024119

Agrawal, A., Dillon, S., Denning, T. L., and Pulendran, B. (2006). ERK1-/- mice exhibit Th1 cell polarization and increased susceptibility to experimental autoimmune encephalomyelitis. J. Immunol. 176, 5788-5796.

Anderton, S. M., van der Zee, R., Prakken, B., Noordzij, A., and van Eden, W. (1995). Activation of T cells recognizing self $60-\mathrm{kD}$ heat shock protein can protect against experimental arthritis. J. Exp. Med. 181, 943-952.

Arispe, N., and De Maio, A. (2000). ATP and ADP modulate a cation channel formed by $\mathrm{Hsc70}$ in acidic phospholipid membranes. J. Biol. Chem. 275, 30839-30843.

Arispe, N., Doh, M., Simakova, O., Kurganov, B., and De Maio, A. (2004). Hsc70 and Hsp70 interact with phosphatidylserine on the surface of $\mathrm{PC} 12$ cells resulting in a decrease of viability. FASEB J. 18, 1636-1645.

Asea, A., Kabingu, E., Stevenson, M. A., and Calderwood, S. K. (2000a). HSP70 peptidembearing and peptide-negative preparations act as chaperokines. Cell Stress Chaperones $5,425-431$.

Asea, A., Kraeft, S. K., Kurt-Jones, E. A., Stevenson, M. A., Chen, L. B., Finberg, R. W., Koo, G. C., and Calderwood, S. K. (2000b). HSP70 stimulates cytokine production through a CD14-dependant pathway, demonstrating its dual role as a chaperone and cytokine. Nat. Med. 6 , 435-442.

Asea, A., Rehli, M., Kabingu, E., Boch, J. A., Bare, O., Auron, P. E., Stevenson, M. A., and Calderwood, S. K. (2002). Novel signal transduction pathway utilized by extracellular HSP70: role of toll-like receptor (TLR) 2 and TLR4. J. Biol. Chem. 277, 1502815034.

Balog, A., Gyulai, Z., Boros, L. G., Farkas, G., Takacs, T., Lonovics, J., and Mandi, Y. (2005). Polymorphism of the TNF-alpha, HSP70-2, and CD14 genes increases susceptibility to severe acute pancreatitis. Pancreas 30 , e46-e50.

Barton, B. E. (2006). STAT3: a potential therapeutic target in dendritic cells for the induction of transplant tolerance. Expert Opin. Ther. Targets 10, 459-470.
Basu, S., Binder, R. J., Ramalingam, T., and Srivastava, P. K. (2001). CD91 is a common receptor for heat shock proteins gp96, hsp90, hsp70, and calreticulin. Immunity 14, 303-313.

Bausinger, H., Lipsker, D., Ziylan, U., Manie, S., Briand, J. P., Cazenave, J. P., Muller, S., Haeuw, J. F., Ravanat, C., de la Salle, H., and Hanau, D. (2002). Endotoxin-free heat-shock protein 70 fails to induce APC activation. Eur. J. Immunol. 32, 3708-3713. Bellmann, K., Hui, L., Radons, J., Burkart, V., and Kolb, H. (1997). Low stress response enhances vulnerability of islet cells in diabetes-prone BB rats. Diabetes 46, 232-236.

Binder, R. J. (2009). CD40-independent engagement of mammalian hsp70 by antigen-presenting cells. J. Immunol. 182, 6844-6850.

Blass, S., Union, A., Raymackers, J., Schumann, F., Ungethum, U., MullerSteinbach, S., de Keyser, F., Engel, J. M., and Burmester, G. R. (2001). The stress protein $\mathrm{BiP}$ is overexpressed and is a major B and $\mathrm{T}$ cell target in rheumatoid arthritis. Arthritis Rheum. 44, 761-771.

Bluestone, J. A. (2005). Regulatory Tcell therapy: is it ready for the clinic? Nat. Rev. Immunol. 5, 343-349.

Bogunia-Kubik, K., and Lange, A. (2005). HSP70-hom gene polymorphism in allogeneic hematopoietic stem-cell transplant recipients correlates with the development of acute graft-versus-host disease. Transplantation 79, 815-820.

Bonorino, C., Nardi, N. B., Zhang, X., and Wysocki, L. J. (1998). Characteristics of the strong antibody response to mycobacterial Hsp70: a primary, $\mathrm{T}$ cell-dependent IgG response with no evidence of natural priming or gamma delta $\mathrm{T}$ cell involvement. $J$. Immunol. 161, 5210-5216.

Boog, C. J., de Graeff-Meeder, E. R., Lucassen, M. A., van der Zee, R., Voorhorst-Ogink, M. M., van Kooten, P. J., Geuze, H. J., and van Eden, W. (1992). Two monoclonal antibodies generated against human hsp60 show reactivity with synovial membranes of patients with juvenile chronic arthritis. J. Exp. Med. 175, 1805-1810.

Borges, T. J., Porto, B. N., Teixeira, C. A., Rodrigues, M., Machado, F. D., Ornaghi, A. P., de Souza, A. P., Maito, F., Pavanelli, W. R., Silva, J. S., and Bonorino, C. (2010). Prolonged survival of allografts induced by mycobacterial Hsp70 is dependent on $\mathrm{CD} 4+\mathrm{CD} 25+$ regulatory $\mathrm{T}$ cells. PLOS ONE 5, el4264. doi: 10.1371/journal.pone.0014264

Botzler, C., Li, G., Issels, R. D., and Multhoff, G. (1998). Definition of extracellular localized epitopes of Hsp70 involved in an NK immune response. Cell Stress Chaperones 3, 6-11.

Broere, F., van der Zee, R., and van Eden, W. (2011). Heat shock proteins are no DAMPs, rather 'DAMPERs'. Nat. Rev. Immunol. 11, 565; author reply 565 .

Brusko, T. M., Putnam, A. L., and Bluestone, J. A. (2008). Human regulatory $\mathrm{T}$ cells: role in autoimmune disease and therapeutic opportunities. Immunol. Rev. 223, 371-390.

Burkart, V., Germaschewski, L., Schloot, N. C., Bellmann, K., and Kolb, H. (2008). Deficient heat shock protein 70 response to stress in leukocytes at onset of type 1 diabetes. Biochem. Biophys. Res. Commun. 369, 421-425.

Bussolati, B., Rollino, C., Mariano, F., Quarello, F., and Camussi, G. (2000). IL-10 stimulates production of platelet-activating factor by monocytes of patients with active systemic lupus erythematosus (SLE). Clin. Exp. Immunol. 122, 471-476.

Chalmin, F., Ladoire, S., Mignot, G., Vincent, J., Bruchard, M., RemyMartin, J. P., Boireau, W., Rouleau, A., Simon, B., Lanneau, D., de Thonel, A., Multhoff, G., Hamman, A., Martin, F., Chauffert, B., Solary, E., Zitvogel, L., Garrido, C., Ryffel, B., Borg, C., Apetoh, L., Rebe, C., and Ghiringhelli, F. (2010). Membrane-associated Hsp72 from tumor-derived exosomes mediates STAT3-dependent immunosuppressive function of mouse and human myeloid-derived suppressor cells. $J$. Clin. Invest. 120, 457-471.

Chen, Y., Kuchroo, V. K., Inobe, J., Hafler, D. A., and Weiner, H. L. (1994). Regulatory T cell clones induced by oral tolerance: suppression of autoimmune encephalomyelitis. Science 265, 1237-1240.

Clarimon, J., Bertranpetit, J., Boada, M., Tarraga, L., and Comas, D. (2003). HSP70-2 (HSPA1B) is associated with noncognitive symptoms in late-onset Alzheimer's disease. J. Geriatr. Psychiatry Neurol. 16, 146-150.

Cohen, I. R. (2007). Biomarkers, self-antigens and the immunological homunculus. J. Autoimmun. 29, 246-249.

Cohen, I. R., and Young, D. B. (1991). Autoimmunity, microbial immunity and the immunological homunculus. Immunol. Today 12, 105-110.

Debler, J., Schiemann, U., Seybold, U., Mussack, T., Landauer, N., Ladurner, R., and Gross, M. (2003). Heatshock protein HSP70-2 genotypes in patients with Crohn's disease: a more severe clinical course with intestinal complications in presence of the PstIpolymorphism. Eur. J. Med. Res. 8, 120-124.

de Graeff-Meeder, E. R., van der Zee, R., Rijkers, G. T., Schuurman, H. J., Kuis, W., Bijlsma, J. W., Zegers, B. J., and van Eden, W. (1991). Recognition of human $60 \mathrm{kD}$ heat shock protein by mononuclear cells from patients with juvenile chronic arthritis. Lancet 337 , 1368-1372.

de Graeff-Meeder, E. R., van Eden, W., Rijkers, G. T., Prakken, B. J., Kuis, W., Voorhorst-Ogink, M. M., van der Zee, R., Schuurman, H. J., Helders, P. J., and Zegers, B. J. (1995). Juvenile chronic arthritis: $T$ cell reactivity to human HSP60 in patients with a favorable course of arthritis. J. Clin. Invest. 95, 934-940.

de Kleer, I. M., Kamphuis, S. M., Rijkers, G. T., Scholtens, L., Gordon, G., de Jager, W., Hafner, R., van de Zee, R., van Eden, W. Kuis, W., and Prakken, B. J. (2003). The spontaneous remission of juvenile idiopathic arthritis is characterized by $\mathrm{CD} 30+\mathrm{T}$ cells directed to human heat-shock protein 60 capable of producing the regulatory cytokine interleukin-10. Arthritis Rheum. 48, 2001-2010.

Delneste, Y., Magistrelli, G., Gauchat, J., Haeuw, J., Aubry, J., Nakamura, K., Kawakami-Honda, N., Goetsch, L. Sawamura, T., Bonnefoy, J., and Jeannin, P. (2002). Involvement of LOX1 in dendritic cell-mediated antigen cross-presentation. Immunity 17 , 353-362.

De Maio, A. (2011). Extracellular heat shock proteins, cellular export vesicles, and the Stress Observation System: a form of communication during injury, infection, and cell damage. It is never known how far a controversial finding will go! Dedicated to Ferruccio Ritossa. Cell Stress Chaperones 16, 235-249.

Dengjel, J., Schoor, O., Fischer, R., Reich, M., Kraus, M., Muller, M., Kreymborg, K., Altenberend, F., Brandenburg, J., Kalbacher, H., Brock, R., Driessen, C., Rammensee, H. G. and Stevanovic, S. (2005). Autophagy promotes MHC class II presentation of peptides from intracellular source proteins. Proc. Natl. Acad. Sci. U.S.A. 102, 7922-7927.

Detanico, T., Rodrigues, L., Sabritto, A. C., Keisermann, M., Bauer, M. E., Zwickey, H., and Bonorino, C. (2004). Mycobacterial heat shock protein 70 induces interleukin-10 production: immunomodulation of synovial cell cytokine profile and dendritic cell maturation. Clin. Exp. Immunol. 135, 336-342. 
Dhingra, S., Bagchi, A. K., Ludke, A. L., Sharma, A. K., and Singal, P. K. (2011). Akt regulates IL-10 mediated suppression of $\mathrm{TNF} \alpha$-induced cardiomyocyte apoptosis by upregulating Stat3 phosphorylation. PLoS ONE 6, e25009. doi: 10.1371/journal. pone.0025009

Dillon, S., Agrawal, A., van Dyke, T., Landreth, G., Mccauley, L., Koh, A., Maliszewski, C., Akira, S., and Pulendran, B. (2004). A Toll-like receptor 2 ligand stimulates Th2 responses in vivo, via induction of extracellular signal-regulated kinase mitogenactivated protein kinase and c-Fos in dendritic cells. J. Immunol. 172, 4733-4743.

Dillon, S., Agrawal, S., Banerjee, K., Letterio, J., Denning, T. L., OswaldRichter, K., Kasprowicz, D. J., Kellar, K., Pare, J., van Dyke, T., Ziegler, S., Unutmaz, D., and Pulendran, B. (2006). Yeast zymosan, a stimulus for TLR2 and dectin-1, induces regulatory antigen-presenting cells and immunological tolerance. J. Clin. Invest. 116, 916-928.

Dong, C., Davis, R. J., and Flavell, R. A. (2002). MAP kinases in the immune response. Annu. Rev. Immunol. 20, 55-72.

Ellis, R. J. (1990). The molecular chaperone concept. Semin. Cell Biol. 1, 1-9.

Feder, M. E., and Hofmann, G. E. (1999). Heat-shock proteins, molecular chaperones, and the stress response: evolutionary and ecological physiology. Annu. Rev. Physiol. 61, 243-282.

Ferrarini, M., Heltai, S., Zocchi, M. R., and Rugarli, C. (1992). Unusual expression and localization of heatshock proteins in human tumor cells. Int. J. Cancer 51, 613-619.

Feuerer, M., Hill, J. A., Mathis, D., and Benoist, C. (2009). Foxp3+ regulatory T cells: differentiation, specification, subphenotypes. Nat. Immunol. 10, 689-695.

Fischer, H. P., Sharrock, C. E., and Panayi, G. S. (1992). High frequency of cord blood lymphocytes against mycobacterial $65-\mathrm{kDa}$ heatshock protein. Eur. J. Immunol. 22, 1667-1669.

Floto, R. A., Macary, P. A., Boname, J. M., Mien, T. S., Kampmann, B., Hair, J. R., Huey, O. S., Houben, E. N., Pieters, J., Day, C., Oehlmann, W., Singh, M., Smith, K. G., and Lehner, P. J. (2006). Dendritic cell stimulation by mycobacterial Hsp70 is mediated through CCR5. Science 314, 454-458.

Frodermann, V., Chau, T. A., Sayedyahossein, S., Toth, J. M., Heinrichs, D. E., and Madrenas, J. (2011). A modulatory interleukin-10 response to staphylococcal peptidoglycan prevents Th1/Th17 adaptive immunity to Staphylococcus aureus. J. Infect. Dis. 204, 253-262.

Gabrilovich, D. I., and Nagaraj, S. (2009). Myeloid-derived suppressor cells as regulators of the immune system. Nat. Rev. Immunol. 9, 162-174.

Gao, B. C., and Tsan, M. F. (2004). Induction of cytokines by heat shock proteins and endotoxin in murine macrophages. Biochem. Biophys. Res. Commun. 317, 1149-1154.

Gehrmann, M., Radons, J., Molls, M., and Multhoff, G. (2008). The therapeutic implications of clinically applied modifiers of heat shock protein 70 (Hsp70) expression by tumor cells. Cell Stress Chaperones 13, 1-10.

Groux, H., O'Garra, A., Bigler, M., Rouleau, M., Antonenko, S., de Vries, J. E., and Roncarolo, M. G. (1997). A CD4+ T-cell subset inhibits antigenspecific T-cell responses and prevents colitis. Nature 389, 737-742.

Halfter, H., Friedrich, M., Postert, C., Ringelstein, E. B., and Stogbauer, F. (1999). Activation of Jak-Stat and MAPK2 pathways by oncostatin M leads to growth inhibition of human glioma cells. Mol. Cell Biol. Res. Commun. 1, 109-116.

Heath, W. R., and Carbone, F. R. (2009). Dendritic cell subsets in primary and secondary $\mathrm{T}$ cell responses at body surfaces. Nat. Immunol. 10, 1237-1244.

Hightower, L. E., and Guidon, P. T. Jr. (1989). Selective release from cultured mammalian cells of heat-shock (stress) proteins that resemble gliaaxon transfer proteins. J. Cell. Physiol. $138,257-266$.

Horwitz, D. A., Zheng, S. G., and Gray, J. D. (2008). Natural and TGFbeta-induced Foxp3(+)CD4(+) $\mathrm{CD} 25(+)$ regulatory $\mathrm{T}$ cells are not mirror images of each other. Trends Immunol. 29, 429-435.

Janson, A. A., Klatser, P. R., van der Zee, R., Cornelisse, Y. E., de Vries, R. R., Thole, J. E., and Ottenhoff, T. H. (1991). A systematic molecular analysis of the $T$ cell-stimulating antigens from Mycobacterium leprae with $\mathrm{T}$ cell clones of leprosy patients. Identification of a novel M. leprae HSP 70 fragment by $M$. leprae-specific T cells. J. Immunol. 147, 3530-3537.

Jenkins, M. K., Chen, C. A., Jung, G., Mueller, D. L., and Schwartz, R. H. (1990). Inhibition of antigen-specific proliferation of type 1 murine $\mathrm{T}$ cell clones after stimulation with immobilized anti-CD3 monoclonal antibody. J. Immunol. 144, 16-22.
Kaiser, F., Cook, D., Papoutsopoulou, S., Rajsbaum, R., Wu, X., Yang, H. T., Grant, S., Ricciardi-Castagnoli, P., Tsichlis, P. N., Ley, S. C., and O'Garra, A. (2009). TPL-2 negatively regulates interferon-beta production in macrophages and myeloid dendritic cells. J. Exp. Med. 206, 1863-1871.

Kammerer, R., Stober, D., Riedl, P., Oehninger, C., Schirmbeck, R., and Reimann, J. (2002). Noncovalent association with stress protein facilitates cross-priming of CD8 $+\mathrm{T}$ cells to tumor cell antigens by dendritic cells. J. Immunol. 168, 108-117.

Kampinga, H. H., Hageman, J., Vos, M. J., Kubota, H., Tanguay, R. M., Bruford, E. A., Cheetham, M. E., Chen, B., and Hightower, L. E. (2009). Guidelines for the nomenclature of the human heat shock proteins. Cell Stress Chaperones 14, 105-111.

Kaufmann, S. H., Vath, U., Thole, J. E., van Embden, J. D., and Emmrich, F. (1987). Enumeration of T cells reactive with Mycobacterium tuberculosis organisms and specific for the recombinant mycobacterial 64 $\mathrm{kDa}$ protein. Eur. J. Immunol. 17, 351-357.

Kimura, Y., Yamada, K., Sakai, T., Mishima, K., Nishimura, H., Matsumoto, Y., Singh, M., and Yoshikai, Y. (1998). The regulatory role of heat shock protein 70-reactive CD4+ $\mathrm{T}$ cells during rat listeriosis. Int. Immunol. 10, 117-130.

Kuma, A., Hatano, M., Matsui, M., Yamamoto, A., Nakaya, H., Yoshimori, T., Ohsumi, Y., Tokuhisa, T., and Mizushima, N. (2004). The role of autophagy during the early neonatal starvation period. Nature 432, 1032-1036.

Li, D., Romain, G., Flamar, A. L., Duluc, D., Dullaers, M., Li, X. H., Zurawski, S., Bosquet, N., Palucka, A. K., Le Grand, R., O'Garra, A., Zurawski, G., Banchereau, J., and Oh, S. (2012). Targeting self- and foreign antigens to dendritic cells via DC-ASGPR generates IL-10-producing suppressive CD4+ T cells. J. Exp. Med. 209, 109-121.

Lindquist, S. (1986). The heat-shock response. Annu. Rev. Biochem. 55, 1151-1191.

Lindquist, S., and Craig, E. A. (1988). The heat-shock proteins. Annu. Rev. Genet. 22, 631-677.

Long, S. A., Rieck, M., Tatum, M., Bollyky, P. L., Wu, R. P., Muller, I., Ho, J. C., Shilling, H. G., and Buckner, J. H. (2011). Low-dose antigen promotes induction of FOXP3 in human CD4+ T cells. J. Immunol. 187, 3511-3520.
Luo, X., Zuo, X., Zhou, Y., Zhang, B., Shi, Y., Liu, M., Wang, K., Mcmillian, D. R., and Xiao, X. (2008). Extracellular heat shock protein 70 inhibits tumour necrosis factor-alpha induced proinflammatory mediator production in fibroblast-like synoviocytes. Arthritis Res. Ther. 10, R41.

Manicassamy, S., Ravindran, R., Deng, J., Oluoch, H., Denning, T. L., Kasturi, S. P., Rosenthal, K. M., Evavold, B. D., and Pulendran, B. (2009). Tolllike receptor 2-dependent induction of vitamin A-metabolizing enzymes in dendritic cells promotes $T$ regulatory responses and inhibits autoimmunity. Nat. Med. 15, 401-409.

Mekala, D. J., Alli, R. S., and Geiger, T. L. (2005). IL-10-dependent infectious tolerance after the treatment of experimental allergic encephalomyelitis with redirected CD4+CD25+ T lymphocytes. Proc. Natl. Acad. Sci. USA 102 11817-11822.

Moore, K. W., de Waal Malefyt, R., Coffman, R. L., and O'Garra, A. (2001). Interleukin-10 and the interleukin10 receptor. Annu. Rev. Immunol. 19, 683-765.

Morelli, A. E., and Thomson, A. W. (2007). Tolerogenic dendritic cells and the quest for transplant tolerance. Nat. Rev. Immunol. 7, 610-621. Motta, A., Schmitz, C., Rodrigues, L., Ribeiro, F., Teixeira, C., Detanico, T., Bonan, C., Zwickey, H., and Bonorino, C. (2007). Mycobacterium tuberculosis heat-shock protein 70 impairs maturation of dendritic cells from bone marrow precursors, induces interleukin-10 production and inhibits T-cell proliferation in vitro. Immunology 121, 462-472.

Multhoff, G., Botzler, C., Wiesnet, M., Muller, E., Meier, T., Wilmanns, W., and Issels, R. D. (1995). A stressinducible $72-\mathrm{kDa}$ heat-shock protein (HSP72) is expressed on the surface of human tumor cells, but not on normal cells. Int. J. Cancer 61 , 272-279.

Munk, M. E., Schoel, B., Modrow, S., Karr, R. W., Young, R. A., and Kaufmann, S. H. (1989). T lymphocytes from healthy individuals with specificity to self-epitopes shared by the mycobacterial and human 65kilodalton heat shock protein. $J$. Immunol. 143, 2844-2849.

Munz, C. (2006). Autophagy and antigen presentation. Cell. Microbiol. 8 , 891-898.

Munz, C. (2009). Enhancing immunity through autophagy. Annu. Rev. Immunol. 27, 423-449.

Murray, P. J. (2006). Understanding and exploiting the endogenous interleukin-10/STAT3-mediated 
anti-inflammatory response. Curr. Opin. Pharmacol. 6, 379-386.

Murray, P. J. (2007). The JAK-STAT signaling pathway: input and output integration. J. Immunol. 178, 2623-2629.

Neefjes, J., Jongsma, M. L., Paul, P., and Bakke, O. (2011). Towards a systems understanding of MHC class I and MHC class II antigen presentation. Nat. Rev. Immunol. 11, 823-836.

Njemini, R., Lambert, M., Demanet, C., Vanden Abeele, M., Vandebosch, S., and Mets, T. (2003). The induction of heat shock protein 70 in peripheral mononuclear blood cells in elderly patients: a role for inflammatory markers. Hum. Immunol. 64, 575-585.

Peluso, I., Fantini, M. C., Fina, D., Caruso, R., Boirivant, M., Macdonald, T. T., Pallone, F., and Monteleone, G. (2007). IL-21 counteracts the regulatory $\mathrm{T}$ cell-mediated suppression of human CD4+ T lymphocytes. J. Immunol. 178, 732-739.

Pockley, A. G., Shepherd, J., and Corton, J. M. (1998). Detection of heat shock protein 70 (Hsp70) and antiHsp70 antibodies in the serum of normal individuals. Immunol. Invest. 27, 367-377.

Prakken, B. J., Wendling, U., van der Zee, R., Rutten, V. P., Kuis, W., and van Eden, W. (2001). Induction of IL-10 and inhibition of experimental arthritis are specific features of microbial heat shock proteins that are absent for other evolutionarily conserved immunodominant proteins. J. Immunol. 167, 4147-4153.

Qin, S., Cobbold, S. P., Pope, H., Elliott, J., Kioussis, D., Davies, J., and Waldmann, H. (1993). "Infectious" transplantation tolerance. Science 259, 974-977.

Quayle, A. J., Wilson, K. B., Li, S. G., Kjeldsen-Kragh, J., Oftung, F., Shinnick, T., Sioud, M., Forre, O., Capra, J. D., and Natvig, J. B. (1992). Peptide recognition, $\mathrm{T}$ cell receptor usage and HLA restriction elements of human heat-shock protein (hsp) 60 and mycobacterial $65-\mathrm{kDa}$ hspreactive $\mathrm{T}$ cell clones from rheumatoid synovial fluid. Eur. J. Immunol. 22, 1315-1322.

Rao, D. V., Watson, K., and Jones, G. L. (1999). Age-related attenuation in the expression of the major heat shock proteins in human peripheral lymphocytes. Mech. Ageing Dev. 107, 105-118.

Roncarolo, M. G., and Battaglia, M. (2007). Regulatory T-cell immunotherapy for tolerance to self antigens and alloantigens in humans. Nat. Rev. Immunol. 7, 585-598.
Rosenblum, M. D., Gratz, I. K., Paw, J. S., Lee, K., Marshak-Rothstein, A., and Abbas, A. K. (2011). Response to self antigen imprints regulatory memory in tissues. Nature 480, 538-542.

Rubtsov, Y. P., Rasmussen, J. P., Chi, E. Y., Fontenot, J., Castelli, L., Ye, X., Treuting, P., Siewe, L., Roers, A., Henderson, W. R. Jr., Muller, W., and Rudensky, A. Y. (2008). Regulatory $\mathrm{T}$ cell-derived interleukin10 limits inflammation at environmental interfaces. Immunity 28 , 546-558.

Rutella, S., Danese, S., and Leone, G. (2006). Tolerogenic dendritic cells: cytokine modulation comes of age. Blood 108, 1435-1440.

Sakaguchi, S., Sakaguchi, N., Asano, M., Itoh, M., and Toda, M. (1995). Immunologic self-tolerance maintained by activated $\mathrm{T}$ cells expressing IL-2 receptor alpha-chains (CD25). Breakdown of a single mechanism of self-tolerance causes various autoimmune diseases. J. Immunol. 155 , 1151-1164.

Sakaguchi, S., Yamaguchi, T., Nomura, T., and Ono, M. (2008). Regulatory T cells and immune tolerance. Cell 133, 775-787.

Saraiva, M., and O'Garra, A. (2010). The regulation of IL-10 production by immune cells. Nat. Rev. Immunol. 10, 170-181.

Schett, G., Redlich, K., Xu, Q., Bizan, P., Groger, M., Tohidast-Akrad, M., Kiener, H., Smolen, J., and Steiner, G. (1998). Enhanced expression of heat shock protein 70 (hsp70) and heat shock factor 1 (HSF1) activation in rheumatoid arthritis synovial tissue. Differential regulation of hsp70 expression and hsfl activation in synovial fibroblasts by proinflammatory cytokines, shear stress, and antiinflammatory drugs. J. Clin. Invest. 102, 302-311.

Schick, C., Arbogast, M., Lowka, K., Rzepka, R., and Melchers, I. (2004). Continuous enhanced expression of Hsc70 but not Hsp70 in rheumatoid arthritis synovial tissue. Arthritis Rheum. 50, 88-93.

Schmid, D., and Munz, C. (2007). Immune surveillance via self digestion. Autophagy 3, 133-135.

Schmid, D., Pypaert, M., and Munz, C. (2007). Antigen-loading compartments for major histocompatibility complex class II molecules continuously receive input from autophagosomes. Immunity 26, 79-92.

Sela, U., Olds, P., Park, A., Schlesinger, S. J., and Steinman, R. M. (2011). Dendritic cells induce antigen-specific regulatory $\mathrm{T}$ cells that prevent graft versus host disease and persist in mice. J. Exp. Med. 208, 2489-2496.

Sharif, M. N., Tassiulas, I., Hu, Y., Mecklenbrauker, I., Tarakhovsky, A., and Ivashkiv, L. B. (2004). IFNalpha priming results in a gain of proinflammatory function by IL10: implications for systemic lupus erythematosus pathogenesis. J. Immunol. 172, 6476-6481.

Shevach, E. M. (2006). From vanilla to 28 flavors: multiple varieties of $\mathrm{T}$ regulatory cells. Immunity 25 , 195-201.

Steinman, R. M., Hawiger, D., and Nussenzweig, M. C. (2003). Tolerogenic dendritic cells. Annu. Rev. Immunol. 21, 685-711.

Steinman, R. M., Turley, S., Mellman, I., and Inaba, K. (2000). The induction of tolerance by dendritic cells that have captured apoptotic cells. $J$. Exp. Med. 191, 411-416.

Stocki, P., Wang, X. N., and Dickinson, A. M. (2012). Inducible Hsp70 reduces $\mathrm{T}$ cell responses and stimulatory capacity of monocyte-derived dendritic cells. J. Biol. Chem. 287, 12387-12394.

Stokes, C. R., Haverson, K., and Bailey, M. (1996). Antigen presenting cells in the porcine gut. Vet. Immunol. Immunopathol. 54, 171-177.

Stordeur, P., and Goldman, M. (1998). Interleukin-10 as a regulatory cytokine induced by cellular stress: molecular aspects. Int. Rev. Immunol. 16, 501-522.

Strawbridge, A. B., and Blum, J. S. (2007). Autophagy in MHC class II antigen processing. Curr. Opin. Immunol. 19, 87-92.

Tanaka, K., Namba, T., Arai, Y., Fujimoto, M., Adachi, H., Sobue, G., Takeuchi, K., Nakai, A., and Mizushima, T. (2007). Genetic evidence for a protective role for heat shock factor 1 and heat shock protein 70 against colitis. J. Biol. Chem. 282, 23240-23252.

Tanaka, S., Kimura, Y., Mitani, A., Yamamoto, G., Nishimura, H., Spallek, R., Singh, M., Noguchi, T., and Yoshikai, Y. (1999). Activation of $T$ cells recognizing an epitope of heatshock protein 70 can protect against rat adjuvant arthritis. J. Immunol. 163, 5560-5565.

Tang, Q., and Bluestone, J. A. (2008). The Foxp3+ regulatory T cell: a jack of all trades, master of regulation. Nat. Immunol. 9, 239-244.

Tarbell, K. V., Petit, L., Zuo, X., Toy, P., Luo, X., Mqadmi, A., Yang, H., Suthanthiran, M., Mojsov, S., and Steinman, R. M. (2007). Dendritic cell-expanded, islet-specific CD4+ CD25+ CD62L + regulatory $\mathrm{T}$ cells restore normoglycemia in diabetic
NOD mice. J. Exp. Med. 204, 191-201.

Theriault, J. R., Adachi, H., and Calderwood, S. K. (2006). Role of scavenger receptors in the binding and internalization of heat shock protein 70 . J. Immunol. 177, 8604-8611.

Theriault, J. R., Mambula, S. S., Sawamura, T., Stevenson, M. A., and Calderwood, S. K. (2005). Extracellular HSP70 binding to surface receptors present on antigen presenting cells and endothelial/epithelial cells. FEBS Lett. 579, 1951-1960.

Thornton, A. M., Korty, P. E., Tran, D. Q., Wohlfert, E. A., Murray, P. E., Belkaid, Y., and Shevach, E. M. (2010). Expression of Helios, an Ikaros transcription factor family member, differentiates thymic-derived from peripherally induced Foxp3 $+\mathrm{T}$ regulatory cells. J. Immunol. 184, 3433-3441.

Tsan, M. F., and Gao, B. (2009). Heat shock proteins and immune system. J. Leukoc. Biol. 85, 905-910.

Udono, H., and Srivastava, P. K. (1993). Heat shock protein 70-associated peptides elicit specific cancer immunity. J. Exp. Med. 178, 1391-1396.

Ueda, G., Tamura, Y., Hirai, I., Kamiguchi, K., Ichimiya, S., Torigoe, T., Hiratsuka, H., Sunakawa, H., and Sato, N. (2004). Tumorderived heat shock protein 70-pulsed dendritic cells elicit tumor-specific cytotoxic T lymphocytes (CTLs) and tumor immunity. Cancer Sci. 95 , 248-253.

Valencia, X., Stephens, G., GoldbachMansky, R., Wilson, M., Shevach, E. M., and Lipsky, P. E. (2006). TNF downmodulates the function of human CD4+CD25hi T-regulatory cells. Blood 108, 253-261.

van Eden, W., Thole, J. E., van der Zee, R., Noordzij, A., van Embden, J. D., Hensen, E. J., and Cohen, I. R. (1988). Cloning of the mycobacterial epitope recognized by $\mathrm{T}$ lymphocytes in adjuvant arthritis. Nature 331, 171-173.

van Eden, W., van der Zee, R., and Prakken, B. (2005). Heat-shock proteins induce $\mathrm{T}$-cell regulation of chronic inflammation. Nat. Rev. Immunol. 5, 318-330.

van Eden, W., Wick, G., Albani, S., and Cohen, I. (2007). Stress, heat shock proteins, and autoimmunity: how immune responses to heat shock proteins are to be used for the control of chronic inflammatory diseases. Ann. NY Acad. Sci. 1113 , 217-237.

van Puijvelde, G. H., van Es, T., van Wanrooij, E. J., Habets, K. L., de Vos, P., van der Zee, R., van Eden, W., van Berkel, T. J., and Kuiper, J. (2007). 
Induction of oral tolerance to HSP60 or an HSP60-peptide activates T cell regulation and reduces atherosclerosis. Arterioscler. Thromb. Vasc. Biol. 27, 2677-2683.

Vega, V. L., Rodriguez-Silva, M., Frey, T., Gehrmann, M., Diaz, J. C., Steinem, C., Multhoff, G., Arispe, N., and de Maio, A. (2008). Hsp70 translocates into the plasma membrane after stress and is released into the extracellular environment in a membrane-associated form that activates macrophages. J. Immunol. 180, 4299-4307.

Vignali, D. A., Collison, L. W., and Workman, C. J. (2008). How regulatory T cells work. Nat. Rev. Immunol. 8, 523-532.

Wang, Y., Kelly, C. G., Karttunen, J. T., Whittall, T., Lehner, P. J., Duncan, L., Macary, P., Younson, J. S., Singh, M., Oehlmann, W., Cheng, G., Bergmeier, L., and Lehner, T. (2001). CD40 is a cellular receptor mediating mycobacterial heat shock protein 70 stimulation of CC-chemokines. Immunity 15, 971-983.

Watowich, S. S., and Liu, Y. J. (2010). Mechanisms regulating dendritic cell specification and development. Immunol. Rev. 238, 76-92.
Wauben, M. H., van der Zee, R., Joosten, I., Boog, C. J., van Dijk, A. M., Holewijn, M. C., Meloen, R. H., and van Eden, W. (1993). A peptide variant of an arthritis-related $\mathrm{T}$ cell epitope induces $\mathrm{T}$ cells that recognize this epitope as a synthetic peptide but not in its naturally processed form. $J$. Immunol. 150, 5722-5730.

Weiner, H. L. (2001). Induction and mechanism of action of transforming growth factor-beta-secreting Th3 regulatory cells. Immunol. Rev. 182, 207-214.

Wendling, U., Paul, L., van der Zee, R. Prakken, B., Singh, M., and van Eden, W. (2000). A conserved mycobacterial heat shock protein (hsp) 70 sequence prevents adjuvant arthritis upon nasal administration and induces IL-10-producing $\mathrm{T}$ cells that cross-react with the mammalian selfhsp70 homologue. J. Immunol. 164, 2711-2717.

Wieten, L., Berlo, S. E., Ten Brink, C. B., van Kooten, P. J., Singh, M., van der Zee, R., Glant, T. T., Broere, F., and van Eden, W. (2009a). IL-10 is critically involved in mycobacterial HSP70 induced suppression of proteoglycan-induced arthritis. PLoS ONE 4, e4186. doi: 10.1371/journal. pone.0004186
Wieten, L., van der Zee, R., Goedemans, R., Sijtsma, J., Serafini, M., Lubsen, N. H., van Eden, W., and Broere, F. (2009b). Hsp70 expression and induction as a readout for detection of immune modulatory components in food. Cell Stress Chaperones 15, 25-37.

Wieten, L., van der Zee, R., Spiering, R., Wagenaar-Hilbers, J., van Kooten, P. Broere, F., and van Eden, W. (2010). A novel heat-shock protein coinducer boosts stress protein Hsp70 to activate $T$ cell regulation of inflammation in autoimmune arthritis. Arthritis Rheum. 62, 1026-1035.

Yamazaki, S., Okada, K., Maruyama, A., Matsumoto, M., Yagita, H., and Seya, T. (2011). TLR2-dependent induction of IL-10 and Foxp3+ $\mathrm{CD} 25+\mathrm{CD} 4+$ regulatory $\mathrm{T}$ cells prevents effective anti-tumor immunity induced by Pam2 lipopeptides in vivo. PLoS ONE 6, e18833. doi: 10.1371/journal.pone.0018833

Yi, A. K., Yoon, J. G., Yeo, S. J. Hong, S. C., English, B. K., and Krieg, A. M. (2002). Role of mitogen-activated protein kinases in CpG DNA-mediated IL-10 and IL-12 production: central role of extracellular signal-regulated kinase in the negative feedback loop of the
CpG DNA-mediated Th1 response. J. Immunol. 168, 4711-4720.

Conflict of Interest Statement: The authors declare that the research was conducted in the absence of any commercial or financial relationships that could be construed as a potential conflict of interest.

Received: 15 December 2011; accepted: 11 April 2012; published online: 04 May 2012.

Citation: Borges TJ, Wieten L, van Herwijnen MJC, Broere F, van der Zee $R$, Bonorino $C$ and van Eden $W$ (2012) The anti-inflammatory mechanisms of Hsp70. Front. Immun. 3:95. doi: 10.3389/fimmu.2012.00095

This article was submitted to Frontiers in Inflammation, a specialty of Frontiers in Immunology.

Copyright (c) 2012 Borges, Wieten, van Herwijnen, Broere, van der Zee, Bonorino and van Eden. This is an open-access article distributed under the terms of the Creative Commons Attribution Non Commercial License, which permits non-commercial use, distribution, and reproduction in other forums, provided the original authors and source are credited. 